\title{
Improving Students' Vocabulary Mastery Through Story Telling Strategy and Hand Puppet Media
}

\author{
Roikhatun Nasikhah, ${ }^{1}$ Udjang Pairin M. Basir ${ }^{2}$ Maskhurin Fajarina ${ }^{3}$ \\ Universitas Hasyim Asy'ari \\ roikhatun729@gmail.com
}

\begin{abstract}
This study aims to investigate the improvement of students' vocabulary mastery through story telling strategy and the use of hand puppet media in grade VI of SDN Keras I Diwek Jombang. This was qualitative and quantitative study employing pretest-posttest individual design. The research population was students in grade VI of SDN Keras I Diwek Jombang in semester 2 in the academic year of 2018/2019. The data were collected by three instrument, those are observation sheet, field notes, and test the tests were administered to investigate students' vocabulary mastery before and after treatment. The test instrument validated through expert judgment by using validation sheet. After tests validated, tests examined to the population in this study. The results of the study showed that the scores of students' vocabulary mastery in the whole class before treatment were 38.3 in cycle 1 and 42.965 in cycle 2. Meanwhile the average of students' score after treatment was 79.63 in cycle 1 and 80.63 in cycle 2 . From the data, it can be concluded that there were effects or improvement of storytelling strategy and hand puppet media on vocabulary mastery in grade VI of SDN Keras I Diwek Jombang in the academic year of 2018/2019
\end{abstract}

Key words: Hand Puppet Media, Vocabulary Mastery

\section{INTRODUCTION}

Learning English is very important, especially for students in Indonesia. One of the aims in learning English is mastering skill or aspect in language. Vocabulary is one of the aspects in English and it becomes the important aspect. Mastering vocabulary can evolve well 
IMPROVING STUDENTS' VOCABULARY MASTERY THROUGH STORY TELLING

STRATEGY AND HAND PUPPET MEDIA

Roikhatun Nasikhah, ${ }^{1}$ Udjang Pairin M. Basir ${ }^{2}$ Maskhurin Fajarina ${ }^{3}$

if it supported by another aspects, those are spelling, pronunciation, and grammar. Standard Competence and Basic Competence in English expected can accommodate students' ability to develop their vocabulary mastery. Teacher expected to be more creative in giving learning experience for students so learning process will be meaningful. This learning is very important for students because students will have the good foundation of science to continue their study to the next level.

Vocabulary is the collection of some words that has meaning to communicate information so information can be easily to be accepted well. Vocabulary is not only a word list. It means that vocabulary is not only word that has meaning without use but also it is a collection of words become a sentence or more to communicate something so it can be meaningful information. Meanwhile, mastery is belongs to someone toward something. In summary, vocabulary mastery is the great skill or knowledge of students in learning vocabulary.

Learning model of vocabulary that mostly used by some teachers is memorizing or translating word by word helped by dictionary. We must know that students, moreover young learners have a fresh brain to memorize something. However students will feel very bored when they learn something that is not their interest. The impression is teacher forces students to always learning something but teacher cannot be students' best guide to find their interest. That is why teachers should be creative to teach students so students will get meaningful learning and learning interest by them self.

See the phenomenon of the problem, presumably necessary to use new innovation in learning vocabulary. In this case, learning language is desirable to do effectively so it can be influenced the process and the result of students' learning. Vocabulary is one of learning language that needs to do effectively. One of many effective ways in teaching vocabulary used by creative teacher is using story telling strategy. Meanwhile, presenting media is very needed to help students in learning process.

Hand puppet media has chosen in learning vocabulary because it can draw students' attention to be more spirit in learning English, especially vocabulary mastery. Hand puppet media is appropriate to use in learning vocabulary. Hand puppet can make students feel happy in learning English through story. Telling a story is an activity to communicate message or information to another person verbally. Gunarti, Suryani, \& Muis (2014:5.5), stated that telling a story can develop students' language ability, among them is listening, speaking, and 
vocabulary that students have will increase well. It can develop students' thinking ability, students' social emotional, instilling moral value, etc. The objective of this study is to know students' improvement of vocabulary mastery by using story telling strategy and hand puppet media in grade VI of SDN Keras I Diwek Jombang in the academic year of 2018/2019. This research has a lot of significances. The significance of study can be theoretical and practical. This research support existing research and it can improve vocabulary learning using story telling strategy and hand puppet media. The result of this research can give direct experience to the teacher to develop teaching and learning using strategy and media that is more innovative and oriented in a process so the learning quality can improve. The result of this research can develop students' vocabulary mastery. The result of this research also can be used as a reference in learning innovation to another teachers and also motivate them to always do innovation to use the appropriate and effective media. By doing this research, it can gain insight and experience about the improvement of students' ability using hand puppet media or without use hand puppet media.

\section{METHODOLOGY}

The research design in this study was Classroom Action Research (CAR) with quantitative approach. The approach of this research is qualitative and quantitative because the aim is to develop and prove the theory to the facts in the field. The design of this research is Collaborative Action Research. This research used one class to do the experiment of learning using hand puppet media.

This research did in SDN Keras I Diwek Jombang. The students are one class at grade VI in the academic year of 2018/2019. The time to do this research is on April 2019. The population of this research is students at grade VI of SDN Keras I Diwek Jombang which are the number of students 20 consisting of 10 male and 10 female.

The research design was Collaborative Action Research using pre-test and post-test. The first, the researcher gave pre-test to know students' early situation. Students got pre-test score. After that, teacher taught students using story telling strategy and hand puppet media to do post-test. There, teacher knew students' progress before treatment and after treatment. If there was a significant improvement of students' score, this research was successful. On the contrarily, if students cannot reach score in average 75 in a whole of the class, so this research should be repeated in the next cycle. 
IMPROVING STUDENTS' VOCABULARY MASTERY THROUGH STORY TELLING

STRATEGY AND HAND PUPPET MEDIA

Roikhatun Nasikhah, ${ }^{1}$ Udjang Pairin M. Basir ${ }^{2}$ Maskhurin Fajarina ${ }^{3}$

Based on the problems explained before, data was needed in this research was the result data of vocabulary mastery. Result data of students' vocabulary mastery analyzed by IBM SPSS version 25 and descriptive analysis using Microsoft office 2010. Data description was maximum score, minimum score, average score, median, modus, standard deviation, and variance.

\section{FINDINGS}

Data of the test in this research was data obtained from the average score of students' vocabulary mastery from pre-test and post-test. The test in this research was individual test consisting of multiple choices and matching to the picture. That data were taken to know students' vocabulary mastery before treatment and after treatment.

Research which has been done obtained two kinds of tests those are test data of students' early vocabulary mastery and test data of students' last vocabulary mastery. Data of students' early vocabulary mastery obtained from doing pre-test and data of students' last vocabulary mastery obtained from doing post-test. Pre-test was test data of students' vocabulary mastery which was given to students before treatment. This pre-test aimed to know students' early ability of the material would be experimented. Post-test was held after finishing experiment activity. This post-test aimed to know students' improvement toward students' vocabulary mastery. In summary, average score of students' vocabulary mastery served at this table.

Table 1. Pre-test and Post-test result of students' vocabulary mastery.

\begin{tabular}{cccc} 
Source & N & $\begin{array}{c}\text { Min } \\
\text { Score }\end{array}$ & $\begin{array}{c}\text { Max } \\
\text { Score }\end{array}$ \\
\hline $\begin{array}{c}\text { Cycle } \\
\mathbf{1}\end{array}$ & & & \\
$\begin{array}{c}\text { Pre- } \\
\text { test }\end{array}$ & 19 & 0 & 66.6
\end{tabular}

M 


\begin{tabular}{ccccc}
$\begin{array}{c}\text { Post- } \\
\text { test }\end{array}$ & 20 & 53.3 & 100 & 79.63 \\
\hline $\begin{array}{c}\text { Cycle } \\
\mathbf{2}\end{array}$ & & & \\
$\begin{array}{c}\text { Pre- } \\
\text { test }\end{array}$ & 20 & 13.3 & 73.3 & 42.965 \\
$\begin{array}{c}\text { Post- } \\
\text { test }\end{array}$ & 20 & 60 & 100 & 80.63 \\
\hline
\end{tabular}

At table 1, the average of students' pre-test in cycle 1 was 38.3 which the number of students was 19 while the post-test was 79.63. Meanwhile in cycle 2, the pre-test average was 42.965 which the number of students was 20 while the post-test was 80.63 . It can be concluded that there was a significant improvement of students' vocabulary mastery before treatment and after treatment. In this research exactly at cycle 1 was successful but the researcher wanted made this research more strong and trusted so the researcher continued this research to the next cycle. That is why the total cycle in this research was 2 cycles.

\section{CONCLUSION}

Known from table 1 that students' average score of pre-test was 38.3 while the average score of post-test was 79.63 which the number of students was 19 in cycle 1 . While in cycle 2 , the students' average score was 42.965 at pre-test and 80.63 at post-test which the number of students was 20. It was known that teaching story for students at grade VI of SDN Keras I Diwek Jombang between story telling strategy using hand puppet media was more effective than without using it. It can be concluded that this research was successful so researcher would stop this research at two cycles.

\section{REFERENCES}

Alizadeh, I. (2016). Vocabulary Teaching Techniques: A Review of Common Practices. International Journal of Research in English Education, 1(1), 22-30. Retrieved from http://ijreeonline.com/article-1-25-en.html

Alqahtani, M. (2015). The Importance of Vocabulary in Language Learning and How to be Taught. International Journal of Teaching and Education, III(3), 21-34. https://doi.org/10.20472/te.2015.3.3.002

Arsyad, A. (2015). Media Pembelajaran. Jakarta: PT RajaGrafindo Persada. 
IMPROVING STUDENTS' VOCABULARY MASTERY THROUGH STORY TELLING

STRATEGY AND HAND PUPPET MEDIA

Roikhatun Nasikhah, ${ }^{1}$ Udjang Pairin M. Basir ${ }^{2}$ Maskhurin Fajarina ${ }^{3}$

Asgari, A., \& Mustapha, G. Bin. (2011). The Type of Vocabulary Learning Strategies Used

by ESL Students in University Putra Malaysia. International Education Studies, 4(2), 84-90. https://doi.org/10.5539/elt.v4n2p84

Asyiah, D. N. (2017). The Vocabulary Teaching and Vocabulary Learning: Perception, Strategies, and Influences on Students' Vocabulary Mastery. Jurnal Bahasa Lingua Scientia, 9(2), 293-318.

Basri, H., Ridla, M. R., \& Wahed, A. (2014). Strategi Belajar Kosakata Bahasa Inggris (English Vocabulary) Mahasiswa TBI STAIN Pamekasan. OKARA, 2, 153-166.

Bull, V. (Ed.). (2008). Oxford Learner's Pocket Dictionary (Fourth edi). China: Oxford University Press.

Coombe, C. (2015). Assessing Vocabulary in the Language Classroom. (February), 111-124. Retrieved from http://marifa.hct.ac.ae/2011/1194

Faliyanti, E., \& Arlin, M. (2018). The Correlation Between Students' Habit in Watching English Movie and Vocabulary Mastery at the Sixth Semester at English Education Study Program in Muhammadiyah University of Metro. Intensive Journal, 1(Vocabulary Mastery), 13-21. Retrieved from http://ojs.uniskabjm.ac.id/index.php/EJB

Farizawati. (2016). Using Storytelling for Teaching Vocabulary. English Education Journal, (Teaching Vocabulary), 246-259.

Gunarti, W., Suryani, L., \& Muis, A. (2014). Metode Pengembangan Perilaku dan Kemampuan Dasar Anak Usia Dini (Kesatu; N. S., Ed.). Tangerang Selatan: Universitas Terbuka.

Guskey, T. R., \& Anderman, E. M. (2014). In Search of a Useful Definition of Mastery. Educational Leadership, 71(Mastery), 18-23.

Hackman, S. (2008). Teaching Effective Vocabulary. In Department for Children, Schools and Families. Nottingham: Department for Children.

Halim, N. S. (2016). The Effectiveness of Using Hand Puppet in Teaching Vocabulary at the Fourth Grade Student of MI Tarbiyatul Athfal Pulotondo. IAIN Tulungagung.

Handayani, D. P. (2016). Meningkatkan Kemampuan Berbahasa Melalui Kegiatan Bercerita Dengan Media Boneka Tangan Pada Anak Di Taman Kanak-Kanak (S. S. Khamim Tohari, Ed.). Lamongan: Kresna Bina Insan Prima.

Hasbiyah, S. (2015). Penerapan Pembelajaran Pendekatan Story Telling Untuk Meningkatkan Penguasaan Mata Pelajaran PAI Materi Kisah Khalifah. Jurnal Ilmu Pendidikan Dasar, 9916, 43-57.

Jannah, M. (2018). Improving Students' Reading Comprehension Through Directed Reading Thinking Activity in Grade VIII of SMPN 5 Jombang. University of Hasyim Asy'ari.

Lestari, A. N. (2015). The Effectiveness of Using Hangaroo Game Toward Students' Vocabulary. Universitas Muhammadiyah Palangkaraya.

Linse, C. T. (2005). Practical English Language Teaching: Young Learners (David Nunan, Ed.). New York: McGraw-Hill.

McCarten, J. (2007). Teaching Vocabulary. Retrieved from www.cambridge.org

Mislaini. (2015). Improving Students' Reading Comprehension of Narrative Text By Using Fable at the Grade X SMAN 1 Bonai Darussalam. JurnaL Mahasiswa FIKIP 
Universitas Pasir Pangaraian, Vol. 1. Pasir Pangairan.

Nugroho, Y. S., Nurkamto, J., \& Sulistyowati, H. (2012). Improving Students' Vocabulary Mastery Using Flashcards. English Education; Jurnal Pendidikan Bahasa Inggris, 1(1), 1-15.Retrievedfrom http://jurnal.fkip.uns.ac.id/index.php/bhs_inggris/article/view/1240

Panggabean, H. (2016). Urgensi Dan Posisi Bahasa Inggris di Indonesia. Retrieved November 26,2018,fromhttps://www.researchgate.net/profile/Himpun_Panggabean/publication/3 13160996_URGENSI_DAN_POSISI_BAHASA_INGGRIS_DI_INDONESIA/links/ 5891a07ba6fdcc1b41467526/URGENSI-DAN-POSISI-BAHASA-INGGRIS-DIINDONESIA

Purnamasari, H. R. (2013). Meningkatkan Kosakata Bahasa Inggris Anak Taman KanakKanak Melalui Metode Bercerita Dengan Menggunakan Media Boneka Jari dan Kartu Bergambar. Universitas Pendidikan Indonesia.

Ryshke, R. (2013). Mastery Learning from 2 Experts. Retrieved November 26, 2018, from https://rryshke.blog/2013/12/07/mastery-learning-from-2-experts/

R., M. (2004). Metode Pengajaran di Taman Kanak-Kanak. Jakarta: Rineka Cipta.

Rasika, D. J., Sukirlan, M., Suka, R. G., \& Sudirman. (2012). The Influence of Story Telling Technique on Students Speaking Ability. University of Lampung.

Sariguam, I. P. (2017). Efektifitas Pemanfaatan Media Boneka Tangan Terhadap Keterampilan Berbicara Peserta Didik Kelas III MIN Likuboddong Kecamatan Bontonompo Kabupaten Gowa. Universitas Islam Negeri Alauddin Makassar.

Susanto, A. (2017). The Teaching of Vocabulary: A Perspective. Jurnal KATA, 1(2), 191. https://doi.org/10.22216/jk.v1i2.2136

Times, Sunday Times. (2012).

Vista, T. (n.d.). Vocabulary. Retrieved January 18, 2019, from NCS Pearson website: http://chemistry.tutorvista.com/analytical-chemistry/equivalencepoint.html\#equivalence-point-definition

Xiqin, L. (2008). A Study of Teaching Strategies To Improve Junior High School English Vocabulary Learning. South China University, Guangzhou, P.R. China.

Zuhriyah, M. (2016). Implementing Think Pair Share Model in Paragraph Writing Class in the Second Semester of English Department of Education Faculty of Hasyim Asy'ari University Tebuireng Jombang in the Academic Year of 2015/2016. Hasyim Asy'ari University. 